\title{
PROFIL PEMAHAMAN KONSEP SEGITIGA PADA SISWA SEKOLAH DASAR (SD) BERDASARKAN TEORI VAN HEILE
}

\author{
${ }^{1}$ Yayuk Purnamawati, ${ }^{2}$ Sardulo Gembong, ${ }^{3}$ Ervina Maret S. \\ ${ }^{1}$ Mahasiswa Prodi Matematika IKIP PGRI Madiun \\ ${ }^{2}$ Dosen Prodi Matematika IKIP PGRI Madiun \\ ${ }^{3}$ Dosen Prodi Matematika IKIP PGRI Madiun
}

\begin{abstract}
Abstrak. Berbagai anggapan muncul di benak siswa sebagai pelaksana pendidikan bahwa matematika adalah mata pelajaran sulit untuk dipahami. Pemahaman meliputi perilaku yang menunjukkan kemampuan siswa dalam menangkap pengertian suatu konsep. Salah satu materi yang perlu penanaman konsep adalah materi segitiga. Pada teori Van Hiele mengatakan bahwa tingkatan untuk pemahaman geometri dasar meliputi 5 tingkatan yaitu tahap informasi, orientasi terbimbing, eksplitasi, orientasi bebas, integrasi. Penelitian ini bertujuan untuk mengetahui mengetahui profil pemahaman konsep segitiga pada siswa Sekolah (SD) berdasarkan teori Van Hiele. Penelitian ini menggunakan jenis pendekatan deskriptif kualitatif. Subjek penelitian adalah 6 siswa kelas III SD N 03 Dimong. Teknik pengumpulan data diperoleh dari metode tes tulis dan tes wawancara. Teknik keabsahan data menggunakan teknik trianggulasi sumber dan teknik sedangkan teknik analisis datanya adalah non-statistik dengan menggunakan transkrip wawancara dan catatan lapangan.

Hasil penelitian menunjukkan bahwa siswa kategori tinggi memiliki kecenderungan pemaham konsep geometri yang baik, siswa kategori sedang memiliki kecenderungan pemaham konsep geometri yang cukup baik sedangkan siswa kategori rendah memiliki pemaham konsep geometri yang kurang.
\end{abstract}

Kata Kunci : Pemahaman Konsep, Konsep Segitiga Dasar, Teori Van Hiele.

\section{PENDAHULUAN}

Sekolah digunakan sebagai upaya memfasilitasi pendidikan di negara kita. Sebagaimana tujuannya, sekolah merupakan suatu tempat yang menyenangkan dan mengasyikkan karena banyak hal yang bisa diperoleh. Berbagai mata pelajaran yang diajarkan di sekolah penting untuk dipahami. Terutama matematika yang menjadi kebutuhan tersendiri bagi manusia dan berguna dalam kehidupan sehari-hari perlu untuk dipelajari. Seperti menurut Cockroft (dalam Hamzah B. Uno dan Masri Kudrat Umar, 2009: 108) matematika perlu dipelajari karena matematika sangat dibutuhkan dan berguna dalam kehidupan sehari-hari, bagi sains, perdagangan dan industri, dan karena matematika itu menyediakan suatu daya, alat komunikasi yang singkat dan tidak ambisius serta berfungsi sebagai alat untuk mendeskripsikan dan memprediksi.
Matematika tidak hanya berhubungan dengan bilangan-bilangan serta operasi-operasinya, melainkan juga unsur ruang sebagai sasarannya. Namun penunjukkan kuantitas seperti itu belum memenuhi sasaran matematika yang lain, yaitu yang ditujukan kapada hubungan, pola, bentuk dan struktur (Tinggih, dalam Herman Hudojo, 2005: 35). Matematika merupakan ilmu penting yang harus diajarkan di sekolah. Hal itu terbukti bahwa matematika merupakan ilmu wajib yang diajarkan di setiap jenjang pendidikan mulai dari sekolah dasar hingga jenjang perguruan tinggi. Bahkan semenjak memasuki pendidikan usia dini anak-anak sudah dikenalkan dengan istilah matematika.

Namun yang menjadi permasalahan dari dahulu hingga sekarang, matematika merupakan salah satu pelajaran yang paling tidak disukai oleh sebagian besar siswa. Matematika dianggap sebagai pelajaran yang sulit dipahami dan tidak menyenangkan. Hal 
tersebut sangatlah berdampak pada hasil belajar siswa maupun tujuan pendidikan. Ketercapaian tujuan pendidikan dan pembelajaran matematika salah satunya dapat dinilai dari keberhasilan siswa dalam memahami matematika dan memanfaatkan pemahaman ini untuk menyelesaikan persoalan-persoalan matematika maupun ilmu-ilmu yang lain. Berbagai anggapan muncul di benak siswa sebagai pelaksana pendidikan bahwa matematika adalah mata pelajaran yang tidak menarik, membosankan dan sulit untuk dipahami. Pemahaman terhadap matematika yang seperti itu membuat siswa merasa kesulitan dalam memahami matematika itu sendiri. Pemahaman meliputi perilaku menerjemahkan, menafsirkan, menyimpulkan, atau mengekstrapolasi (memperhitungkan) konsep dengan menggunakan kata-kata atau simbolsimbol lain yang dipilihnya sendiri. Dengan kata lain pemahaman meliputi perilaku yang menunjukkan kemampuan siswa dalam menangkap pengertian suatu konsep (M. Atwi Suparman, 2012: 135). Anggapan-anggapan tentang matematika tersebut harusnya bisa hilang apabila siswa sudah paham betul tentang konsep dasar dari materi yang diajarkan.

Woodruf mendefinisikan konsep sebagai suatu gagasan atau ide yang relatif sempurna dan bermakna, suatu pengertian tentang suatu objek, produk subjektif yang berasal dari cara seseorang membuat pengertian tentang suatu objek atau benda-benda melalui pengalamannya setelah melakukan persepsi terhadap objek atau benda (carapedia.com). Salah satu materi yang perlu penanaman konsep adalah materi segitiga. Banyak siswa yang masih belum bisa memahami tentang konsep segitiga secara baik. Contohnya salah satu siswa yang diberi soal untuk menghitung luas segitiga siku-siku siswa tersebut menyelesaikan soal dengan nilai akhir benar, namun jika bentuk segitiga diganti dengan segitiga sama kaki, penyelesaian siswa tersebut salah. Setelah ditanya tentang penyelesaian mereka ternyata mereka salah menunjukkan mana alas dan tingginya. Artinya siswa tersebut belum paham tentang segitiga. Padahal segitiga merupakan materi dasar yang perlu dikuasai oleh siswa, terutama siswa sekolah dasar. Materi segitiga tersebut nantinya digunakan sebagai materi prasyarat pada jenjang berikutnya seperti pada materi bangun ruang limas segitiga, prisma tegak segitiga, trapezium, teorema pythagoras, kerucut dan masih banyak lagi. Apabila pada sekolah dasar siswa belum memahami konsep segitiga maka pada materimateri geometri yang lain akan mengalami kesulitan. Artinya segitiga merupakan dasar dari pemahaman materi yang lain.

Segitiga merupakan salah satu materi pada geometri. Sehingga berkenaan dengan kusulitan dan permasalahan tentang geometri tersebut, ada suatu teori yang berkaitan dengan pemahaman geometri pada pembelajaran geometri yaitu Teori Van Hiele. Teori ini tingkat berfikir geometri siswa secara berurutan melalui 5 tingkatan/level, yaitu; level 0 (visualisasi), level 1 (analisis), level 2 (informasi deduksi), level 3 (deduksi), level 4 (rigor). Sedangkan untuk meningkatkan kemampuan berfikir geometri pada tingkat dasar terdiri dari 5 tahapan yaitu; (1) tahap informasi, (2) tahap orientasi terpandu/terbimbing, (3) tahap eksplisitasi, (4) tahap orientasi bebas, (5) tahap intregasi.

Berdasarkan permasalahan tentang bagaimana profil pemahaman konsep segitiga pada siswa sekolah dasar berdasarkan teori Van Hiele? Maka dilakukan penelitian dengan tujuan untuk mengetahui profil pemahaman konsep segitiga pada siswa Sekolah (SD) berdasarkan teori Van Hiele. 
Adapun beberapa teori yang perlu di pelajari dalam penelitian ini diantaranya adalah:

\section{Pemahaman konsep}

Sumarmo (dalam Epon Nur'aeni, 2008: 129) mengemukakan, secara umum indikator pemahaman matematika meliputi; mengenal, memahami dan menerapkan konsep, prosedur, prinsip dan ide matematika. Pemahaman konseptual dalam matematika dapat dijabarkan antara lain; a) Mengenali, melabelkan, dan membuat contoh serta non contoh konsep. b) Mengenali, menginterprestasikan, dan menerapkan tanda, simbol dan istilah yang digunakan untuk merepresentasikan konsep c) Membandingkan, membedakan, dan menghubungkan konsep dengan prinsip siswa dalam pelajaran dapat dilihat dari (1) kemampuan mengekspresikan ideide matematika melalui lisan, tertulis, dan mendemonstrasikannya serta menggambarkannya secara visual; (2) kemampuan memahami, menginterpretasikan, dan mengevaluasi ide-ide matematika baik secara lisan, tulisan, mau pun dalam bentuk visual lainnya; (3) kemampuan dalam menggunakan istilah, notasi-notasi matematika dan struktur-strukturnya, untuk menyajikan ide-ide, menggambarkan hubungan-hubungan dan model-model. Suyono dan Hariyanto (2011: 168-169) mengemukakan bahwa indikator pemahaman meliputi menerjemahkan makna pengetahuan, menafsirkan, dan mengekstrapolasi. Paparan perilaku pemahaman di antaranya memahami makna, menyatakan data dengan katakata sendiri, menafsirkan, ekstrapolasi, dan menerjemahkan.

Berdasarkan pendapat-pendapat di atas dapat disimpulkan bahwa pemahaman meliputi kegiatan mengenali, melabelkan, membuat contoh serta bukan contoh, menginterprestasikan, membandingkan, membedakan, menghubungkan konsep.
Woodruf (carapedia.com) mendefinisikan konsep sebagai adalah suatu gagasan/ide yang relatif sempurna dan bermakna, suatu pengertian tentang suatu objek, produk subjektif yang berasal dari cara seseorang membuat pengertian terhadap objek-objek atau benda-benda melalui pengalamannya (setelah melakukan persepsi terhadap objek/benda). Pada tingkat konkrit, konsep merupakan suatu gambaran mental dari beberapa objek atau kejadian yang sesungguhnya. Pada tingkat abstrak dan komplek, konsep merupakan sintesis sejumlah kesimpulan yang telah ditarik dari pengalaman dengan objek atau kejadian tertentu.

Soedjadi mendefinisikan konsep adalah ide abstrak yang digunakan untuk menagadakan klasifikasi atau penggolongan yang apad umumnya dinyatakan dengan suatu istilah atau rangakaian kata.

Bahri menjelaskan konsep adalah satuan ahli yang mewakili sejumlah objek yang mempunyai ciri yang sama.

Berdasarkan beberapa pendapat di atas maka dapat diambil kesimpulan bahwa konsep adalah arti abstrak dari berbagai objek-objek yang dihadapi untuk menyederhanakan pemikiran menjadi satu istilah yang terungkap atau tidak terungkap dan peristiwa-peristiwa itu termasuk atau tidak termasuk ke dalam ide abstrak tersebut.

\section{Pemahaman konsep geometri (segitiga)}

Tidak semua orang berpikir tentang ide-ide geometri dengan cara yang sama. Riset dari dua pendidik, Pierre Van Hielle dan Dina Van Hielle - Geldof (dalam Walle, 2006: 151) menghasilkan wawasan dalam pemikiran geometri dan bagaimana perbedaan tersebut muncul. Riset Van Hielle bermula pada tahun 1959 dan langsung menarik perhatin di Uni Soviet. Teori Van Hielle ini telah menjadi faktor yang paling berpengaruh dalam kurikulum geometri di Amerika. 
Adapun tingkat-tingkat pemikiran Van Hielle adalah :Level 0: Visualisasi, objek-objek pemikiran pada level 0 berupa bentuk-bentuk dan bagaimana rupa mereka. Siswa pada tingkatan awal mengenal dan menanamkan bentukbentuk berdasarkan pada karakteristik luas dan tampilan dari bentuk-bentuk tersebut. Siswa mampu membuat pengukuran dan tentang sifat-sifat bentuk, tetapi sifat-sifat tersebut tidak terpisahkan dari wujud yang sebenarnya. Sebuah bujur sangkar dikatakan bujur sangkar karena terlihat seperti bujur sangkar. Karena wujud atau tampilan suatu objek sangat dominan maka dari wujud atau tampilan tersebut dapat menentukan sifat-sifat dari suatu bentuk. Sebagai contoh, sebuah bujur yang telah diputar sehingga bersudut $45^{\circ}$ dari vertikal mungkin jadi belah ketupat, bukan lagi sebuah bujur sangkar. Siswa pada tingkatan ini akan mengklasifikasikan bentuk berdasarkan wujud atau tampilannya. Hasil pemikiran pada level 0 adalah kelaskelas atau kelompok-kolompok dari bentuk yang terlihat mirip. Level 1: Analisis, objek-objek pemikiran pada level 1 berupa kelompok-kelompok benyuk bukan bentuk-bentuk individual. Siswa pada tingkat analisis dapat menyatakan semua bentuk dalam golongan selain bentuk satuannya. Hasil dari pemikiran pada level 1 adalah sifatsifat dari bentuk. Level 2: Deduksi Informal,objek pada pemikiran level 2 adalah sifat-sifat dari bentuk. Jika siswa mulai dapat berfikir tentang sifat-sifat objek geometri tanpa batasan dari objek tertentu, mereka dapat membuat hubungan di antara sifat-sifat tersebut. " jika keempat sudut merupakan siku-siku, bangun tersebut sudah pasti persegi panjang. Jika bentuknya persegi, semua titik sudutnya sudah pasti siku-siku. Jika bentuknya persegi, bangun tersebut juga merupakan persegi panjang". Dengan pemahaman yang lebih untuk berurusan dengan pemikiran "jika-maka", bentuk- bentuk dapat digolongkan hanya dengan menggunakan pencirian yang minimal. Hasil pemikiran pada level 2 adalah hubungan diantara sifat-sifat objek geometri. Kegiatan-kegiatan pada tingkatan ini ditandai dengan adanya pencantuman dari pemikiran logis informal. Siswa telah mengadakan pemahaman pada berbagai sifat bentuk. Level 3: Deduksi, objek pemikiran pada level 3 berupa hubungan di antara sifatsifat objek geometri. Pada tingkat ini, siswa mampu meneliti bukan hanya sifat-sifat bentuk saja. Pemikiran mereka sebelumnya telah menghasilkan dugaan mengenai hubungan antar sifat-sifat. Siswa pada tingkatan ini mampu bekerja dengan pernyataan-pernyataan abstrak tentang sifat-sifat geometri dan membuat kesimpulan lebih berdasarkan pada logika daripada naluri. Hasil pemikiran pada level 3 berupa sistemsistem deduktif dasar dari geometri. Siswa membuat daftar aksioma, definisi untuk membuat teorema, dan membuktikan teorema tersebut dengan menggunakan pemikiran logis yang terartikulasi. Level 4: Ketepatan, objekobjek pemikiran pada level 4 berupa sistem-sistem deduktif dasar dari geometri. Pada tingkatan teratas dalam tingkatan Van Hiele, objek-objek perhatian adalah system dasarnya sendiri, bukan hanya penyimpulan dalam system. Hasil pemikiran pada tingkat 4 ini berupa sistem-sistem deduktif kasar dari geometri.

Pembelajaran geometri dengan tahap van hiele pada tingkatan dasar meliputi tingkat 1 (visualisasi) dengan tujuan untuk peningkatkan pemahaman konsep dasar geometri siswa dengan materi segitiga (dalam Epon Nur'aeni, 2008: 127). Tahapan tersebut terdiri dari 5 tahap yaitu: 1) Tahap Informasi, pada tahapan ini guru berusaha mengali pengetahuan yang telah dimiliki siswa tentang materi segitiga. Guru memberikan pertanyaan, misalnya; 1) apakah anak-anak sudah pernah 
mendengar tentang segitiga? 2) coba sebutkan benda apa saja yang berbentuk segitiga? 2) Tahap Orientasi Terpadun atau Terbimbing, dari berbagai ragam bentuk segitiga, siswa dapat menunujukkan dapat membedakan bangun segitiga dengan bangun yang lainnya. Guru meminta siswa untuk; 1) membangdingkan antara segitiga dan bukan segitiga 2) mengukur sisi-sisi segitiga 3) menggambar segitiga dan 4) mengidentifikasi segitiga. 3) Tahap Eksplitasi, siswa mengekspresikan konsep segitiga yang sudah dipahami dengan menggunakan kata-kata sendiri berdasarkan tampilan bentuk. Misalnya segitiga adalah yang bentuknya mirip dengan atap rumah, yaitu memiliki tiga sisi dan tiga sudut. Guru membimbing siswa agar menggunakan kosakata yan baik dan benar. 4) Tahap Orientasi Bebas, siswa menemukan caranya sendiri dalam memahami konsep segitiga dengan menganalisis sifat-sifat khusus dari bentuk geometri yang tersedia. 5) Tahap Integrasi, merupakan tahap terakhir pada perkembangan kognitif siswa dalam memahami segitiga. Dalam tahap ini siswa sudah dapat memahami pentingnya ketepatan dari prinsip dasar yang melandasi suatu penelitian. Siswa dapat membuat rangkuman atau ringkasan tentang segitiga setelah proses orientasi.

\section{METODE PENELITIAN}

Tempat dan waktu penelitian, Penelitian ini dilaksanakan di SDN 03 Dimong Kec./Kab. Madiun pada bulan Februari sampai Juli 2013.

Pendekatan dan jenis penelitian, Peneliti menggunakan jenis pendekatan deskriptif kualitatif. Penelitian dilakukan dengan pemberian tes tertulis dan wawancara kepada subyek penelitian. Data yang dihasilkan dari penelitian ini adalah data deskriptif yang berupa katakata tertulis atau lisan. Sumber data, Sumber data yang digunakan pada penbelitian ini mencakup data dari wali kelas III SDN 03 Dimong, hasil tes tulis dan hasil tes wawancara dari subyek penelitian. 1) Teknik pengumpulan data Teknik penggumpulan data yang digunakan terdiri dari dua metode yaitu metode tes dan metode wawancara. 2) Prosedur penelitian, Prosedur penelitian yang dipakai sebagai berikut: a) Tahap persiapan meliputi observasi dan penyusunan soal tes tulis dan wawancara terkait dengan segitiga. b) Tahap pelaksanaan meliputi pemberian tes tulis dan tes wawancara, c) Tahap analisis meliputi reduksi data, penyajian data, verifikasi dan penarikan kesimpulan d) Tahap penyusunan laporan, Teknik keabsahan data, Keabsahan atau validitas menggunakan teknik trianggulasi data sampai mendapatkan data yang linear. Kelinieran data melalui teknik trianggulasi itulah yang akan digunakan untuk mengukur validitas data tersebut. Untuk mendapatkan data yang valid, peneliti menggunakan uji kredibilitas data dengan triangulasi sumber dan teknik.

Teknik analisis data Penelitian ini merupakan penelitian kualitatif, maka analisis datanya adalah non-statistik. Peneliti menggunakan transkrip wawancara, catatan lapangan dan bahanbahan lain untuk menyajikan hasil penelitian.

\section{HASIL PENELITIAN}

Analisis dilakukan sebanyak 6 siswa penelitian dengan tingkatan yang berbeda diantaranya tingkat tinggi, sedang dan rendah. Adapun proses berpikir kreatif siswa SD (Sekolah Dasar) dalam menyelesaiakan soal dengan materi segitiga sebagai berikut.

1. Aspek pemahaman mengenali dari 6 subyek terdiri dari aspek yaitu kode Mm1 dan Mm2. Subyek dengan kategori tinggi dan rendah semuanya mempunyai kode yang 
sama yaitu Mm1 yang berarti bahwa subyek mempunyai kemampuan untuk mengetahui atau mengenali dengan satu ciri atau informasi. Subyek dengan kategori sedang mempunyai kode $\mathbf{M m} \mathbf{1}$ dan Mm2, kode Mm1 yang berarti subyek mempunyai kemampuan untuk mengetahui atau mengenali dengan satu ciri atau informasi, sedangkan kode $\mathbf{M m} 2$ berarti subyek mempunyai kemampuan untuk dapat mengenali atau mengetahui dengan dua ciri.

2. Aspek pemahaman melabelkan dari 6 subyek tidak beragam, semua siswa memenuhi kode Ml1. Subyek dengan kategori tinggi, sedang, dan rendah mempunyai kemampuan untuk dapat melabelkan atau memberi nama lebih dari satu masalah.

3. Aspek pemahaman membuat contoh dan bukan contoh dari 6 subyek beragam. Subyek dengan kategori tinggi keduanya mempunyai kode Mc1, yang berarti subyek mempunyai kemampuan untuk dapat membuat lebih dari satu contoh dan bukan contoh tentang suatu istilah. Subyek kategori sedang keduanya mempunyai kode Mc2 berarti mempunyai kemampuan untuk dapat membuat satu contoh dan bukan contoh tentang suatu istilah. Subyek dengan kategori rendah mempunyai dua kode yaitu Mc2 dan Mc3. Subyek dengan kategori rendah mempunyai kode $\mathbf{M c 2}$ yang berarti subyek dapat membuat satu contoh dan bukan contoh tentang suatu istilah. Sedangkan subyek dengan kategori rendah mempunyai kode $\mathbf{M c 3}$ yang berarti subyek tidak dapat membuat contoh dan bukan contoh tentang suatu istilah.

4. Aspek pemahaman menginterpretasikan dari 6 subyek sama. Subyek dengan kategori tinggi, sedang, dan rendah mempunyai kode Mk3 yang berarti subyek tidak dapat menginterpretasikan dengan bahasanya sendiri dalam penyelesaian masalah.

5. Aspek pemahaman membandingkandari 6 subyek terdiri dari 2 kode yaitu Ms2 dan Ms3. Subyek dengan kategori tinggi mempunyai kode yang sama yaitu Ms2, yang berarti bahwa subyek dapat mengetahui perbedaan antara dua benda atau lebih namun tidak dapat menjelaskannya. Subyek dengan kategori sedang mempunyai kode Ms2 dan Ms3 yang berarti kode Ms2, subyek dapat mengetahui perbedaan antara dua benda atau lebih namun tidak dapat menjelaskannya. Ms3 berarti subyek tidak dapat mengetahui perbedaan antara dua benda atau lebih namun tidak dapat menjelaskannya. Subyek dengan kategori rendah mempunyai kode yang sama yaitu Ms3, yang berarti subyek tidak dapat mengetahui perbedaan antara dua benda atau lebih namun tidak dapat menjelaskannya.

6. Aspek pemahaman membedakan dari 6 subyek terdiri dari 2 kode yaitu kode Mp1 dan Mp2. Subyek dengan kategori tinggi mempunyai kode yang sama yaitu Mp1, yang berarti subyek dapat membedakan atau menyatakan adanya perbedaan antara lebih dari dua benda. Subyek dengan kategori sedang mempunyai kode Mp1 dan Mp2 yang berarti kode, Mp1 subyek mempunyai kemampuan untuk dapat membedakan atau menyatakan adanya perbedaan lebih dari dua benda. Mp2 berarti subyek tidak dapat membedakan atau menyatakan adanya perbedaan suatu benda. Subyek dengan 
kategori rendah mempunyai kode yang sama yaitu Mp2, yang berarti subyek tidak dapat membedakan atau menyatakan adanya perbedaan suatu benda.

7. Aspek pemahaman menghubungkan konsep dari 6 subyek mempunyai kode yang sama yaitu Mh3. Subyek dengan kategori tinggi, sedang, dan rendah mempunyai kode $\mathbf{M h 3}$, yang berarti bahwa subyek tidak dapat mengaitkan konsep ke dalam materi, masalah, atau sub bab lain.

\section{A. PEMBAHASAN}

Berdasarkan data hasil temuan peneliti, adapun hasil temuan dari analisis tes tulis dan wawancara berdasarkan pengkodean deskriptor. Berdasarkan hasil analisis data tes tulis dan wawancara yang termuat di tabel 5.1 di atas dapat dilihat di kolom 2 memiliki kode Mm1 pada subyek kategori tinggi, sedang dan rendah yang berarti memiliki kemampuan untuk mengetahui tandatandanya atau ciri-cirinya dengan indikator baik, sehingga subyek dapat mengenali atau mengetahui dengan 1 ciri saja.

1. Berdasarkan hasil analisis data tes tulis dan wawancara yang termuat di tabel 5.1 di atas dapat dilihat di kolom 3 memiliki kode Mm2 pada subyek kategori sedang yang berarti memiliki kemampuan untuk mengetahui tanda-tandanya atau ciri-cirinya dengan indikator cukup, sehingga subyek dapat mengenali atau mengetahui dengan dua ciri saja.

2. Berdasarkan hasil analisis data tes tulis dan wawancara yang termuat di tabel 5.1 di atas dapat dilihat di kolom 5 memiliki kode MI1 pada subyek kategori tinggi, sedang dan rendah yang berarti memiliki kemampuan untuk memberikan label atau nama dengan indikator baik, sehingga subyek dapat melabelkan atau memberi nama lebih dari satu masalah.

3. Berdasarkan hasil analisis data tes tulis dan wawancara yang termuat di tabel 5.1 di atas dapat dilihat di kolom 8 memiliki kode Mc1 pada subyek kategori tinggi yang berarti memiliki kemampuan membuat contoh dan bukan contoh dengan ungkapan ataupun dengan gambar.

4. Berdasarkan hasil analisis data tes tulis dan wawancara yang termuat di tabel 5.1 di atas dapat dilihat di kolom 9 memiliki kode Mc2 pada subyek kategori sedang yang berarti memiliki kemampuan untuk dapat membuat satu contoh dan bukan contoh tentang suatu istilah.

5. Berdasarkan hasil analisis data tes tulis dan wawancara yang termuat di tabel 5.1 di atas dapat dilihat di kolom 10 memiliki kode Mc3 pada subyek kategori rendah yang berarti tidak memiliki kemampuan untuk dapat membuat satu contoh dan bukan contoh tentang suatu istilah.

6. Berdasarkan hasil analisis data tes tulis dan wawancara yang termuat di tabel 5.1 di atas dapat dilihat di kolom 13 memiliki kode Mk3 pada subyek kategori tinggi, sedang dan rendah yang berarti tidak dapat menginterpretasikan dengan bahasanya sendiri dalam penyelesian masalah.

7. Berdasarkan hasil analisis data tes tulis dan wawancara yang termuat di tabel 5.2 di atas dapat dilihat di kolom 3 memiliki kode Ms2 pada subyek kategori tinggi, dan sedang yang berarti subyek dapat mengetahui perbedaan antara dua benda atau lebih dan dapat menjeleskannya.

8. Berdasarkan hasil analisis data tes tulis dan wawancara yang termuat di tabel 5.2 di atas dapat dilihat di kolom 4 memiliki kode Ms3 pada subyek kategori sedang, dan rendah yang berarti subyek tidak dapat 
mengetahui perbedaan antara dua benda atau lebih dan tidak dapat menjeleskannya.

9. Berdasarkan hasil analisis data tes tulis dan wawancara yang termuat di tabel 5.2 di atas dapat dilihat di kolom memiliki kode Mp1 pada subyek kategori tinggi, dan sedang yang berarti subyek dapat membedakan atau menyatakan adanya perbedaan antara lebih dari dua benda.

10. Berdasarkan hasil analisis data tes tulis dan wawancara yang termuat di tabel 5.2 di atas dapat dilihat di kolom 6 memiliki kode Mp2 pada subyek kategori sedang, dan rendah yang berarti subyek dapat membedakan atau menyatakan adanya perbedaan dari dua benda saja.

11. Berdasarkan hasil analisis data tes tulis dan wawancara yang termuat di tabel 5.2 di atas dapat dilihat di kolom 10 memiliki kode Mh3 pada subyek kategori tinggi, sedang, dan rendah yang berarti subyek tidak dapat mengeitkan konsep ke dalam materi lain atau sub bab lain.

\section{KESIMPULAN DAN SARAN}

\section{Kesimpulan Penelitian}

Berdasarkan hasil penelitian dan pembahasan yang diperoleh dapat diambil suatu kesimpulan profil pemahaman konsep siswa dalam materi segitiga siswa kelas III sebagai berikut: a) Siswa kategori tinggi memiliki kecenderungan pemaham konsep geometri yang baik. Siswa dapat mengenali, melabelkan, membuat contoh dan bukan contoh, dan membedakan bangun geometri dengan baik. b) Siswa kategori sedang memiliki kecenderungan pemaham konsep geometri yang cukup baik. Siswa dapat melabelkan bangun geometri dengan baik namun aspek membuat contoh dan bukan contoh, membedakan bangun geometri dengan cukup. c) Siswa kategori rendah memiliki pemaham konsep geometri yang kurang. Siswa tidak dapat membuat contoh dan bukan contoh dan tidak dapat membandingkan bangun geometri.

\section{Saran}

\section{Bagi guru}

Pada aspek membandingkan siswa hanya dapat mengetahui dua benda itu berbeda namun siswa tersebut tidak dapat menjelaskan letak perbedaannya. Maka seharusnya siswa lebih sering diberikan pengetahuan dan penjelasan secara terperinci tentang perbedaan dari berbagai jenis segitiga. Dalam menginterpretasikan, siswa tidak dapat menginterpretasikan dengan bahasanya sendiri dalam penyelesaian masalah. Maka seharusnya guru melatih siswa untuk menggunakan pemahaman mereka untuk mengampaikan suatu istilah bukan menggunakan hafalan mereka. Sedangkan pada aspek menghubungkan konsep, siswa belum mampu untuk mengaitkan konsep suatu materi ke dalam materi lain atau sub materi lain. Oleh karena itu dalam pembelajaran guru sering mengaitkan hubungan materi dengan kehidupan yang dekat dengan dunia siswa.

\section{Bagi sekolah}

Sekolah sebagai lembaga pendidikan formal dan sebagai sarana untuk meningkatkan mutu pendidikan, maka dari itu kepala sekolah hendaknya mendukung pembelajaran kelas yang lebih mengutamakan pemahaman siswa dengan memberikan sarana dan prasarana yang dapat membantu guru untuk menyampaikan materi dengan baik. Bagi peneliti lain yang tertarik pada penelitian yang sejenis hendaknya memperhatikan keadaan, situasai tempat penelitian, dan keadaan siswa agar mempermudah dalam penelitian. Serta hendaknya penelitian dilakukan pada kelas dan pokok bahasan yang berbeda. 


\section{DAFTAR PUSTAKA}

.Pengertian Definisi Konsep Menurut Para Ahli. (online), (http://carapedia.com/pengertian _definisi_konsep_menurut_para _ahli_info402.html, diunduh 20 Januari 2013).

Epon Nur'aeni. 2008. Teori van heile dan komunikasi matematik (apa, mengapa dan bagaimana). Makalah disajikan dalam Seminar Nasional Matematika dan Pendidikan Matematika, Dosen Pendidikan Guru Sekolah Dasar (PGSD), UPI Kampus Tasikmalaya.

Hamzah B. Uno dan Masri Kudrat Umar. 2009. Mengelola Kecerdasan dalam
Pembelajaran. Jakarta: Bumi Aksara.

Herman Hudojo. 2005. Pengembangan Kurikulum dan Pembelajaran Matematika. Malang: Universitas Negeri Malang Press.

John A. Van de Walle. 2006. Matematika Pengembangan Pengajaran jilid 2. Jakarta: Erlangga.

M. Atwi Suparman. 2012. Desain Instruksional Modern: Panduan Para Pengajar dan Inovator Pendidikan. Jakarta: PT Gelora Aksara Pratama

Suyono dan Hariyanto. 2011. Belajar dan Pembelajaran. Bandung: PT Remaja Rosdakarya 